\title{
A note on translation and transliteration
}

This book adheres to the spelling conventions for the Indonesian language introduced in 1972. Many Indonesians have continued to write their personal names in the old spelling. However, in some instances, I have opted for the current variant, changing Hasjim Asj ${ }^{c}$ ari to Hasyim $\mathrm{Asy}^{\mathrm{c}}$ ari, and writing Sukarno and Suharto, rather than Soekarno and Soeharto. The spelling of names is further complicated by the parallel use of Indonesian and Javanese. For example, Hamengkubuwono in Javanese is Hamengkubuwana in Indonesian. In the literature, some scholars have adhered to the Indonesian, others to the Javanese versions. For Javanese names, I have opted for retaining the original spelling. Another challenge is that Indonesian has its own system of transliterating Arabic terms, which deviates from authoritative alternatives used in academic sources written in European languages. When relying on sources related to Indonesia, I have respected the Indonesian conventions, in other instances I have used a simplified version of the transcription used in the International fournal of Middle East Studies (IFMES); dispensing with diacritics for long vowels and consonants with no (near) equivalents in European languages. Those with relevant linguistic qualifications will be able to establish the original Arabic anyway, while other readers need not be burdened with a possibly distracting idiosyncratic typography. 